\title{
Effect of Packaging Materials with Ethylene Absorbents on Quality of Banana Fruits Cv. Martaman
}

\author{
Reshmi Kumari $^{{ }^{*}}$, Neha Kumari ${ }^{1}$ and Payel Panja ${ }^{2}$ \\ ${ }^{1}$ Deputy Director of Horticulture, Satna-485001, Madhya Pradesh, India \\ ${ }^{2}$ Department of Post-Harvest Technology of Horticultural Crops, Bidhan Chandra Krishi \\ Viswavidyalaya, Mohanpur, Nadia-741252, West Bengal, India \\ *Corresponding author
}

\section{A B S T R A C T}

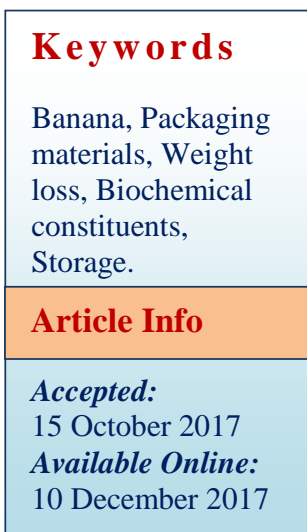

An experiment was conducted during the period of 2014-15 at the Department of PostHarvest Technology of Horticultural Crops, Faculty of Horticulture, Bidhan Chandra Krishi Viswavidyalaya, West Bengal to study the effect of treatments on quality of banana fruits. Banana fruits cv. Martaman were packed in different plastic packages (1\% perforated HDPE, $2 \%$ perforated HDPE, un-perforated HDPE, $1 \%$ perforated LDPE, $2 \%$ perforated LDPE and un-perforated LDPE) with ethylene absorbents and placed in ambient condition whereas control was without packaging. The fruits were examined for physiological parameters i.e., physiological loss in weight (PLW), shelf life, ripening and biochemical characteristics viz., TSS, titratable acidity, ascorbic acid, total and reducing sugar. The results revealed that fruits cv. Martaman packed in un-perforated LDPE with ethylene absorbent under ambient condition proved to be the better treatment than rest of the treatments. The treatment effectively reduced PLW \%, also rich in ascorbic acid and there is more gradual decrease in TSS, total and reducing sugar than other treatments up to $12^{\text {th }}$ day. But as per sensory quality the maximum score was attained in $2 \%$ perforated LDPE $\left(T_{5}\right)$ for $\mathrm{cv}$. Martaman. These treatments enhanced shelf life and maximum retention of nutritional quality.

\section{Introduction}

Banana (Musa paradisiaca L.) belonging to the family Musaceae, is one of the most important fruit crop of the world. It is a tropical, herbaceous, monocotyledonous and monocarpic fruit crop. In India banana is predominant and popular among the people as they are relished and consumed by all kind of people. Considering the nutrition and fruit values of banana it is believed to be the "Poor Man's Apple" (Patel et al., 2010) and it is the cheapest among all the fruits in the country. India is the largest banana producer and consumer country in the world followed by China, contributing about $39 \%$ of the total world production. The post-harvest losses of fresh banana fruits go up to $30-40 \%$ due to improper handling, storage (Patil and Hulamani, 1998) and other reasons like browning, abrasion, senescence, skin discoloration, fungal decay etc. Banana is a very perishable fruits and it possess very short shelf life nearly 10-12 days under ambient condition, both ripe and unripe banana is very susceptible to mechanical damage. Banana is 
hardly compatible with other crops in mixed load in storage or during transport because it produces high amount of ethylene and also susceptible to chilling injury. Lack of storage facilities, limited access to transportation and risk of high losses, growers are often forced to dispose off their produce over a short period of time (Haidar and Demisse, 1999) which causes an economic loss of banana.

When fruits approach maturity, they release ethylene which promotes to ripening. Among the many changes that ethylene causes is the destruction of chlorophyll. Thus ethylene plays an essential role in the ripening of climacteric fruit. Banana being climacteric fruit, control of ethylene will solve many of the problems. Use of ethylene absorbent at such temporary storage will postpone the untimely climacteric process. Ethylene absorbent acts as oxidizing agent, which oxidized ethylene to acetaldehyde $\left(\mathrm{CH}_{3} \mathrm{CHO}\right)$, which in turn is oxidized to acetic acid $\left(\mathrm{CH}_{3} \mathrm{COOH}\right)$. Acetic acid is further oxidized to carbon dioxide $\left(\mathrm{CO}_{2}\right)$ and water $\left(\mathrm{H}_{2} \mathrm{O}\right)$. This loss can be kept at minimum by improving postharvest handling techniques through the use of packaging materials or through improving traditional packaging practices. Use of ethylene absorbent during transport will retard the chances of untimely ripening during transport. The study was undertaken with a view to make this technology available to regional farmers at a reasonable price, to enhance shelf life of banana by using ethylene absorbent and storing in different packaging materials.

\section{Materials and Methods}

The present experiment was carried out under the laboratory conditions in the department of Post-Harvest Technology of Horticultural Crops, Bidhan Chandra Krishi Viswavidyalaya, Mohanpur, Nadia, West Bengal during the year of 2014-15. Banana fruits cv. Martaman were harvested at properly matured but unripe stage and brought to the laboratory for post-harvest study. The hands were separated from the bunch. Washing of fruits was done in tap water and then in distilled water containing 50 ppm of chlorine $\left(\mathrm{CaCl}_{2}\right)$ to reduce the microbial load, after that they were kept under fan for surface drying at room temperature. The temperature ranges from $17^{0} \mathrm{C}-33.05^{\circ} \mathrm{C}$ and relative humidity $70-92 \%$ during the month of October to December. Banana fruits after proper surface drying were packed with different packaging materials viz., $1 \%$ perforated High Density Polyethylene $\left(\mathrm{T}_{1}\right)$, 2\% perforated High Density Polyethylene $\left(\mathrm{T}_{2}\right)$, un-perforated High density polythene $\left(\mathrm{T}_{3}\right), \quad 1 \%$ perforated Low Density Polyethylene $\left(\mathrm{T}_{4}\right), 2 \%$ perforated Low Density Polyethylene $\left(\mathrm{T}_{5}\right)$, un-perforated Low Density Polythene $\left(\mathrm{T}_{6}\right)$ and one ethylene absorbent sachets $\left(4 \mathrm{gm} \mathrm{KMnO}_{4} / \mathrm{Kg}\right.$ of fruit) was placed in each bag. Fruits without packaging and ethylene absorbent were kept as control $\left(\mathrm{T}_{7}\right)$ for comparison. 10 fruits were placed in each polyethylene bag.

Physiological loss in weight was calculated on the basis of initial weight at three days interval and expressed in percent (\%). Titratable acidity was measured by titrating fruit juice with $0.1 \mathrm{NaOH}$ with phenolphthalein as an indicator. The data was statistically analyzed as per the method given in A.O.A.C. (1990). Total soluble solid (TSS) was estimated by hand refractometer (0$\left.32^{\circ} \mathrm{B}\right)$. The readings obtained were calibrated against a standard temperature at $20^{\circ} \mathrm{C}$ as per the International Temperature Correction Table and expressed as ${ }^{\circ}$ Brix. Ascorbic acid was determined by standard method (AOAC, 1990) and results were expressed as percentage citric acid of juice. Total sugars and reducing sugars were measured by the method of Ranganna (2000). Colour, flavor and overall acceptability were assessed based 
on the hedonic scale (Ranganna, 2000). The analysis of the data obtained in experiment was analyzed by Completely Randomized Design method. Standard error (S.Em \pm ) and the critical difference $(\mathrm{P}=0.05)$ for all effects were calculated (Gomez and Gomez, 1984).

\section{Results and Discussion}

\section{Physiological loss in weight (\%) and} ripening $(\%)$

The effects of different packaging and ethylene absorbent on PLW \% of cv. Martaman in ambient condition are being presented in Table 1 and they were highly significant. It can be seen that in general, weight losses increased considerably in all the treatments with progress of storage period but control fruits recommended higher PLW \% throughout the storage period. Whereas fruits packed in un-perforated LDPE $\left(\mathrm{T}_{6}\right)$ recommended minimum PLW \% throughout the storage period. On $12^{\text {th }}$ day maximum PLW \% (10.37\%) was observed in control fruits $\left(\mathrm{T}_{7}\right)$ and minimum $(0.67 \%)$ was recorded in un-perforated HDPE $\left(\mathrm{T}_{3}\right)$, followed by $\mathrm{T}_{6}(1.31 \%)$ after which fruits deteriorates in un-perforated $\operatorname{HDPE}\left(\mathrm{T}_{3}\right)$ and control $\left(\mathrm{T}_{7}\right)$ in storage period. But on $15^{\text {th }}$ day of storage least PLW\% was observed in unperforated LDPE $\left(\mathrm{T}_{6}\right)$ with a loss of $1.38 \%$. Stover and Simmonds (1987) reported that banana fruits loss weight due to respiration and transpiration as a result of the appearance, textural and nutritional qualities of the fruit were negatively affected.

As can be seen from table longest shelf life 18 days was observed in un-perforated LDPE $\left(\mathrm{T}_{6}\right)$ followed by $1 \%$ perforated LDPE $\left(\mathrm{T}_{4}\right)$ i.e., 17 days. The shortest shelf life was seen in $\mathrm{T}_{7}$ (control) which deteriorated after $12^{\text {th }}$ days of storage. In general, un-perforated LDPE $\left(\mathrm{T}_{6}\right)$ extends the shelf life by 6 days over control. The significant increase in the ripening (\%) of banana with ethylene absorbent was more pronounced from the starting and the trend continued up to 15 days of storage. Untreated fruits showed $100 \%$ ripening on $10^{\text {th }}$ day whereas treated fruit showed after $12^{\text {th }}$ day of storage under ambient condition. In general un-perforated LDPE $\left(\mathrm{T}_{6}\right)$ recorded minimum ripe fruit percentage $(90 \%)$ on 15 days of storage which was statistically different from other packaging products.

\section{Titratable acidity (\%)}

The data showing change in percentage of titratable acidity in banana due to different packaging materials and ethylene absorbent. Treatments also produced significant effect on $3^{\text {rd }}$ to $12^{\text {th }}$ days of storage at $5 \%$ level of critical difference. The acidity contents of the fruits were increased initially from 0 to 3 days which could be due to the synthesis of organic acids from carbohydrate. After that it was decreased this could be due to its utilization of organic acids as a substrate and by conversion of acids into sugars.

Table 2 showed that the acidity content of $T_{3}$ (un-perforated HDPE) was significantly superior throughout the period of storage from $3^{\text {rd }}$ to $12^{\text {th }}$ day of storage i.e., at $3^{\text {rd }}$ $(0.53 \%), 6^{\text {th }}(0.45 \%), 9^{\text {th }}(0.43 \%)$ and $12^{\text {th }}$ day $(0.38 \%)$ of storage, which was statistically different from the other treatments at $3^{\text {rd }}$ and $12^{\text {th }}$ day of storage but was at par with $\mathrm{T}_{6}$ at $6^{\text {th }}$ and $9^{\text {th }}$ day of storage. Thus, treated fruits exhibited a tendency to retain more acidity during storage. The lowest value of acidity was observed in $\mathrm{T}_{7}$ (control) with $0.17 \%$ acidity in the $12^{\text {th }}$ day of storage. The result corroborates the findings of Gowen (1995), who reported that in the course of ripening free acidity increases until it reaches fully ripe stage and then free acidity decreased gradually thereafter. 
Table.1 Effect of packaging and ethylene absorbent on the physiological loss in weight, Shelf Life and ripening of banana fruits cv. Martaman

\begin{tabular}{|c|c|c|c|c|c|c|c|c|c|c|}
\hline \multirow[t]{2}{*}{ Treatment } & \multicolumn{5}{|c|}{ PLW (\%) } & \multirow{2}{*}{$\begin{array}{c}\text { Shelf life } \\
\text { (days) }\end{array}$} & \multicolumn{4}{|c|}{ Ripening (\%) } \\
\hline & 3 days & 6 days & 9 days & 12 days & 15days & & 6 days & 9days & 12days & 15days \\
\hline $\mathbf{T}_{1}$ & 1.91 & 2.22 & 2.43 & 2.56 & 2.7 & 16.17 & 30 & 55 & 85 & 98 \\
\hline $\mathbf{T}_{2}$ & 0.94 & 1.56 & 3.22 & 4.63 & 4.8 & 15.25 & 35 & 60 & 90 & 100 \\
\hline $\mathbf{T}_{\mathbf{3}}$ & 0.04 & 0.34 & 0.62 & 0.67 & - & 13.55 & 49 & 85 & 100 & - \\
\hline $\mathbf{T}_{4}$ & 0.33 & 1.65 & 2.89 & 3.85 & 3.92 & 17.18 & 25 & 55 & 80.3 & 95.3 \\
\hline $\mathbf{T}_{5}$ & 0.63 & 1.57 & 2.57 & 3.95 & 3.99 & 16.23 & 30 & 60 & 85.3 & 100 \\
\hline$T_{6}$ & 0.29 & 0.63 & 1.20 & 1.31 & 1.38 & 18.35 & 20 & 50 & 75.3 & 90 \\
\hline $\mathbf{T}_{7}$ & 1.32 & 3.64 & 6.60 & 10.37 & - & 12.13 & 65 & 89 & 100 & - \\
\hline SE.m( $( \pm)$ & 0.013 & 0.045 & 0.043 & 0.037 & 0.035 & 0.101 & 1.294 & 0.634 & 0.35 & 0.436 \\
\hline CD $(0.05 \%)$ & 0.038 & 0.136 & 0.13 & 0.113 & 0.121 & 0.306 & 3.924 & 1.922 & 1.061 & 1.324 \\
\hline
\end{tabular}

Table.2 Effect of packaging and ethylene absorbent on titratable acidity and TSS of banana fruits cv. Martaman

\begin{tabular}{|c|c|c|c|c|c|c|c|c|c|c|}
\hline \multirow{2}{*}{ Treatment } & \multicolumn{5}{|c|}{ Titratable acidity $(\%)$} & \multicolumn{5}{|c|}{$\operatorname{TSS}\left({ }^{0} \mathbf{B}\right)$} \\
\hline & 0 days & 3 days & 6 days & 9days & 12days & 0 days & 3 days & 6 days & 9 days & 12 days \\
\hline $\mathbf{T}_{1}$ & 0.15 & 0.41 & 0.33 & 0.32 & 0.3 & 10.5 & 14.63 & 19.26 & 22.17 & 24.51 \\
\hline $\mathbf{T}_{2}$ & 0.15 & 0.33 & 0.27 & 0.27 & 0.21 & 10.5 & 15.96 & 20.16 & 22.77 & 25.17 \\
\hline $\mathbf{T}_{\mathbf{3}}$ & 0.15 & 0.53 & 0.45 & 0.43 & 0.38 & 10.5 & 14.06 & 18 & 21.33 & 23.83 \\
\hline $\mathbf{T}_{4}$ & 0.15 & 0.39 & 0.34 & 0.32 & 0.27 & 10.5 & 14.46 & 18.93 & 21.97 & 24.17 \\
\hline $\mathbf{T}_{5}$ & 0.15 & 0.30 & 0.28 & 0.26 & 0.19 & 10.5 & 14.94 & 19.66 & 22.50 & 25.04 \\
\hline $\mathbf{T}_{6}$ & 0.15 & 0.46 & 0.42 & 0.4 & 0.35 & 10.5 & 13.83 & 17.43 & 21.03 & 23.33 \\
\hline $\mathbf{T}_{7}$ & 0.15 & 0.25 & 0.23 & 0.22 & 0.17 & 10.5 & 16.33 & 21.16 & 23.87 & 25.33 \\
\hline SE.m( $( \pm)$ & - & 0.011 & 0.013 & 0.012 & 0.006 & - & 0.229 & 0.229 & 0.214 & 0.138 \\
\hline CD $(0.05 \%)$ & - & 0.033 & 0.041 & 0.036 & 0.018 & - & 0.693 & 0.675 & 0.65 & 0.419 \\
\hline
\end{tabular}


Table.3 Effect of packaging and ethylene absorbent on ascorbic acid and total sugar of banana fruits cv. Martaman

\begin{tabular}{|c|c|c|c|c|c|c|c|c|c|c|}
\hline \multirow{2}{*}{ Treatment } & \multicolumn{5}{|c|}{ Ascorbic acid(mg/100g) } & \multicolumn{5}{|c|}{ Total sugar $(\%)$} \\
\hline & 0 days & 3 days & 6 days & 9days & 12days & Odays & 3days & 6days & 9days & 12days \\
\hline $\mathbf{T}_{1}$ & 4.29 & 5.77 & 8.00 & 6.08 & 5.25 & 2.089 & 4.1 & 7.80 & 11.18 & 17.37 \\
\hline $\mathbf{T}_{2}$ & 4.29 & 5.14 & 7.05 & 5.63 & 4.82 & 2.089 & 4.42 & 8.08 & 12.25 & 17.93 \\
\hline $\mathbf{T}_{3}$ & 4.29 & 6.17 & 8.51 & 6.33 & 5.82 & 2.089 & 3.41 & 7.07 & 10.63 & 16.42 \\
\hline $\mathbf{T}_{4}$ & 4.29 & 5.43 & 7.63 & 5.90 & 5.04 & 2.089 & 3.93 & 7.33 & 10.74 & 16.77 \\
\hline $\mathbf{T}_{5}$ & 4.29 & 4.93 & 6.73 & 5.55 & 4.42 & 2.089 & 4.17 & 7.93 & 11.93 & 17.77 \\
\hline $\mathbf{T}_{6}$ & 4.29 & 6.00 & 8.22 & 6.22 & 5.60 & 2.089 & 3.08 & 6.93 & 10.08 & 15.97 \\
\hline $\mathbf{T}_{7}$ & 4.29 & 4.67 & 6.03 & 5.04 & 4.37 & 2.089 & 4.67 & 9.63 & 14.00 & 18.83 \\
\hline SE.m( $( \pm)$ & - & 0.097 & 0.093 & 0.155 & 0.097 & - & 0.073 & 0.091 & 0.15 & 0.118 \\
\hline CD $(0.05 \%)$ & - & 0.295 & 0.282 & 0.471 & 0.294 & - & 0.223 & 0.277 & 0.455 & 0.358 \\
\hline
\end{tabular}

Table.4 Effect of packaging and ethylene absorbent on reducing sugar of banana fruits cv. Martaman

\begin{tabular}{|c|c|c|c|c|c|}
\hline \multirow{2}{*}{ Treatment } & \multicolumn{5}{|c|}{ Reducing sugar (\%) } \\
\hline & 0 days & 3 days & 6 days & 9days & 12days \\
\hline $\mathbf{T}_{1}$ & 1.085 & 2.07 & 2.90 & 4.90 & 6.57 \\
\hline $\mathbf{T}_{2}$ & 1.085 & 2.60 & 3.54 & 5.63 & 7.06 \\
\hline $\mathbf{T}_{3}$ & 1.085 & 1.77 & 2.43 & 4.08 & 6.04 \\
\hline $\mathbf{T}_{4}$ & 1.085 & 2.00 & 2.79 & 4.67 & 6.30 \\
\hline $\mathbf{T}_{5}$ & 1.085 & 2.42 & 3.11 & 5.22 & 6.97 \\
\hline $\mathbf{T}_{6}$ & 1.085 & 1.93 & 2.20 & 3.90 & 5.90 \\
\hline $\mathbf{T}_{7}$ & 1.085 & 2.90 & 4.42 & 6.73 & 7.67 \\
\hline SE.m( $( \pm)$ & - & 0.059 & 0.123 & 0.078 & 0.094 \\
\hline CD $(0.05 \%)$ & - & 0.18 & 0.373 & 0.237 & 0.286 \\
\hline
\end{tabular}




\section{Int.J.Curr.Microbiol.App.Sci (2017) 6(12): 1916-1924}

Table.5 Effect of packaging and ethylene absorbent on sensory score of banana fruits cv. Martaman

\begin{tabular}{|c|c|c|c|c|c|c|c|c|c|}
\hline \multirow{2}{*}{ Treatment } & \multicolumn{3}{|c|}{ Colour (10) } & \multicolumn{3}{c|}{ Flavour (10) } & \multicolumn{3}{c|}{ Overall (20) } \\
\cline { 2 - 10 } & 6 days & 9 days & 12 days & 6 days & 9 days & 12 days & 6 days & 9 days & 12 days \\
\hline $\mathbf{T}_{\mathbf{1}}$ & 6.40 & 7.60 & 8.06 & 5.76 & 6.46 & 7.63 & 12.16 & 14.00 & 15.70 \\
\hline $\mathbf{T}_{\mathbf{2}}$ & 7.40 & 7.90 & 8.40 & 6.60 & 7.16 & 8.23 & 14.00 & 15.00 & 16.60 \\
\hline $\mathbf{T}_{\mathbf{3}}$ & 6.20 & 7.50 & 7.70 & 4.80 & 5.80 & 7.10 & 11.00 & 13.30 & 14.80 \\
\hline $\mathbf{T}_{\mathbf{4}}$ & 6.80 & 7.30 & 8.13 & 6.16 & 6.80 & 7.83 & 12.90 & 14.10 & 15.90 \\
\hline $\mathbf{T}_{\mathbf{5}}$ & 7.20 & 8.16 & 8.70 & 7.00 & 7.46 & 8.73 & 14.20 & 15.60 & 17.40 \\
\hline $\mathbf{T}_{\mathbf{6}}$ & 6.43 & 7.60 & 7.90 & 5.43 & 6.20 & 7.20 & 11.80 & 13.80 & 15.10 \\
\hline $\mathbf{T}_{\mathbf{7}}$ & 7.50 & 8.60 & 8.10 & 7.86 & 8.33 & 6.93 & 15.32 & 16.90 & 15.00 \\
\hline SE.m () & 0.045 & 0.061 & 0.062 & 0.120 & 0.087 & 0.098 & 0.165 & 0.148 & 0.160 \\
\hline CD (0.05\%) & 0.137 & 0.184 & 0.188 & 0.363 & 0.262 & 0.298 & 0.500 & 0.446 & 0.486 \\
\hline
\end{tabular}




\section{Total soluble solids (\%)}

TSS is a major quality parameter, which is correlated with the texture and composition (Kamiloglu, 2011). The data showed a constant increase in TSS value during the course of storage with untreated control maintaining higher values for TSS.

Control fruits $\left(\mathrm{T}_{7}\right)$ showed maximum TSS $\left(25.33^{\circ}\right.$ Brix) on $12^{\text {th }}$ day, was at per with $\mathrm{T}_{2}$ $\left(25.17{ }^{\circ}\right.$ Brix $)$ and $\mathrm{T}_{5} \quad(25.04 \%)$. Unperforated LDPE $\left(\mathrm{T}_{6}\right)$ and un-perforated HDPE $\left(\mathrm{T}_{3}\right)$ showed minimum TSS content of 23.33 and $23.83^{\circ}$ Brix, respectively on the same day of storage. Stover and Simmonds (1987) reported that the conversion of starch into sugars to be the most important change in ripening bananas. Un-perforated polyethylene bags are known to reduce loss of moisture and hydrolysis of polysaccharides resulting in less increase in TSS.

\section{Ascorbic acid (mg/100 gm)}

Data in the Table 3 shows that there was a significant variation for the effect of different treatments on the ascorbic acid content of cv. Martaman fruits. The ascorbic acid contents of the fruits increased initially from 0 to 6 days after that decreased gradually during the storage in all treatments. The highest retention of ascorbic acid content was seen in treatment $\mathrm{T}_{3}$ (un-perforated HDPE) during storage i.e., at $3^{\text {rd }}(6.17 \mathrm{mg} / 100 \mathrm{~g}), 6^{\text {th }}(8.51 \mathrm{mg} / 100 \mathrm{~g}), 9^{\text {th }}$ $(6.33 \mathrm{mg} / 100 \mathrm{~g})$ and $12^{\text {th }}$ day $(5.82 \mathrm{mg} / 100 \mathrm{~g})$ of storage, which was at par with $\mathrm{T}_{6}$ at $3^{\text {rd }}$ and $12^{\text {th }}$ day of storage but at $9^{\text {th }}$ day, it was statistically similar with $\mathrm{T}_{1}, \mathrm{~T}_{4}$ and $\mathrm{T}_{6}$. The maximum loss was observed in $T_{7}$ throughout the period of storage. The loss in ascorbic acid content with the progress of storage period could be attributed to rapid conversion of L-ascorbic acid into dihydro-ascorbic acid in the presence of L-ascorbic acid oxidase (Basir and Abu-Goukh, 2002).

\section{Total sugar $(\%)$}

The changes in total sugar content as influence by various treatments was studied and detail given in Table 3. It is observed that total sugar percentage increased with advancement of storage period up to $12^{\text {th }}$ day for all treatments. Total sugar of $\mathrm{T}_{6}$ (unperforated LDPE) remained significantly low throughout the storage period i.e., at $3^{\text {rd }}(3.08$ $\%), 6^{\text {th }}(6.93 \%), 9^{\text {th }}(10.08 \%)$ and $12^{\text {th }}$ day $(15.97 \%)$ of storage which was statistically different from the other treatments at $3^{\text {rd }}, 9^{\text {th }}$ and $12^{\text {th }}$ day of storage but was at par with $\mathrm{T}_{3}$ $(7.07 \%)$ on $6^{\text {th }}$ day of storage. However, the maximum total sugar was seen in $\mathrm{T}_{7}$ (control) during storage under ambient condition which was statistically different from all the other treatments. The present study was in line with the report of Dadzie and Orchard (1997) that, the most striking postharvest chemical change which occurs during the postharvest ripening of banana is the hydrolysis of starch and the accumulation of sugar (that is, sucrose, glucose and fructose) which are responsible for the sweetening of the fruit.

\section{Reducing sugar (\%)}

Data given in Table 4 indicates that among the treatments there were significantly differences with respect to reducing sugars. From the result it can be observed that reducing sugar content in all the treatments exhibited a continuous increase throughout the storage period. Maximum reducing sugars was observed in case of control $\left(\mathrm{T}_{7}\right)$ in ambient storage and continued upto $12^{\text {th }}$ day of storage which was statistically different with other treatments. Reducing sugars was minimum in $\mathrm{T}_{6}$ (un-perforated LDPE) which was $5.90 \%$ on the $12^{\text {th }}$ day of storage that was significantly at par with $\mathrm{T}_{3}(6.04 \%)$ (unperforated HDPE). Similar results were observed at $6^{\text {th }}(2.20 \%)$ and $9^{\text {th }}$ day $(3.90 \%)$ of storage which was statistically similar with 
$\mathrm{T}_{3}$. But at $3^{\text {rd }}$ day of storage lowest was in $\mathrm{T}_{3}$ $(1.77 \%)$, was at per with $\mathrm{T}_{6}(1.93 \%)$. The increase in the reducing sugar content of banana fruits could be due to hydrolysis of starch into soluble sugars as banana fruit ripen (Stover and Simmonds, 1987).

\section{Sensory score for colour, flavour and overall sensory score}

The sensory score for colour, flavor and overall sensory score of fruits as affected by various treatments are given in Table 5. The sensory score for colour increased gradually during period of storage. The highest sensory score for colour (8.70) was observed in $\mathrm{T}_{5}$ ( $2 \%$ perforated LDPE) at about $12^{\text {th }}$ day of storage and $\mathrm{T}_{3}$ (un-perforated HDPE) had minimum sensory score (7.70) whereas, they are statistically different from the other treatments. An upward trend was noticed in the sensory score for flavour during storage period. $\mathrm{T}_{5}$ (2\% perforated LDPE) obtained the highest sensory score for flavour (8.73) at $12^{\text {th }}$ day of storage. Minimum sensory score (6.93) was recorded in $\mathrm{T}_{7}$ (control) which was at per with $\mathrm{T}_{3}$ (7.1) and $\mathrm{T}_{6}$ (7.2). This might be due to lower percentage of relative humidity in the storage room. The overall sensory score of all fruits as affected by various treatments showed an increasing trend. Treatment $\mathrm{T}_{5}$ ( $2 \%$ perforated LDPE) was able to retain much of its overall quality and recorded a highest overall score (17.4) for cv. Martaman and it was statistically different from other treatments. The treatment $T_{3}$ (un-perforated HDPE) was recorded with lowest score (14.8). The loss of green colour is due to chlorophyll degradation, which subsequently reveals the yellow carotenoid pigments (Marriott and Lancaster, 1983; Stover and Simmonds, 1987).

From the results it was observed that different plastic packages with ethylene absorbents significantly enhanced shelf life and also retention of nutritional quality. Results of ambient conditions indicated that, there was upward trend in PLW, ripening, TSS, total and reducing sugar content with the increasing of storage time while titratable acidity was increased initially from 0 to 3 days and then decreased. The ascorbic acid contents of the fruits increased initially from 0 to 6 days after that decreased gradually during the storage time in all treatments. Among the treatments studied, cv. Martaman packed in un-perforated LDPE with ethylene absorbent under ambient condition proved to be the better treatment than rest of the treatments. The treatment effectively reduced PLW, also rich in ascorbic acid and there is more gradual decrease in TSS, total and reducing sugar than other treatments during storage period. But as per sensory quality the maximum score was attained in $2 \%$ perforated LDPE $\left(\mathrm{T}_{5}\right)$ for $\mathrm{cv}$. Martaman.

\section{Acknowledgement}

We are thankful to the Department of PostHarvest Technology of Horticultural Crops (Horticulture), Bidhan Chandra Krishi Viswavidyalaya, West Bengal, India for providing the laboratory facilities and technical support.

\section{References}

AOAC, 1990.Official methods of analysis. $13^{\text {th }}$ ed., Association of Official Analytical Chemist Benjamin Franklin Station, Washington D.C., USA.

Basir, A.H. and Abu-Goukh, A. 2002. Compositional changes during guava fruit ripening. Food Chemistry, 80 (4): 557-563.

Dadzie, B.K. and Orchard, J.E. 1997. Routin postharvest screening of banana/plantain hybrids criteria and methods. International network for banana and plantain (Inibap), 
Technical Guidelines. Rome, Italy.

Gomez, A.K. and Gomez, A.A. 1984.Statistical procedure for agricultural research. $2^{\text {nd }}$ ed., John Wiley and Sons, Singapore.

Gowen, S. R. 1995. Pests. In S. R. Gowen, ed. Bananas and Plantains. Chapman and Hall, London, UK. pp. 382-402

Haidar, J. and Demisse, T. 1999. Malnutrition and Xerophthagma in rural community Ethiopia. East African Medical Journal, 10: 590-593.

Kamiloglu, O. 2011. Influence of some cultural practices on yield, fruit quality and individual anthocyanins of table grape cv. 'HorozKarasi'. Journal of Animal and Plant Sciences, 21(2): 240- 245.

Marriott, J. and Lancaster, P.A. 1983. Bananas and plantains. In: Harvey TC
$\mathrm{Jr}$ (ed.) Handbook of tropical foods. Marcel Dekker, Inc. pp. 85-142.

Patel, N.I., Padhiar, B.V. and Patel N.B. 2010. Effect of post-harvest treatments on storage life of banana. The Asian Journal of Horticulture, 5(1): 80-84.

Patil, S.N. and Hulmani, N.C. 1998. Effect of post-harvest treatments on the storage of banana fruits. Karnataka Journal of Agricultural Research, 11(1): 134-138.

Ranganna, S. 2000. Handbook of Analysis of Quality control for Fruit and Vegetables products. $2^{\text {nd }}$ ed., Tata McGraw Hill Publication Company. New Delhi. 182189.

Stover, R.H. and Simmonds, N.W. 1987. Bananas. $3^{\text {rd }}$ ed. Tropical agricultural series. Longman, New York.

\section{How to cite this article:}

Reshmi Kumari, Neha Kumari and Payel Panja. 2017. Effect of Packaging Materials with Ethylene Absorbents on Quality of Banana Fruits Cv. Martaman. Int.J.Curr.Microbiol.App.Sci. 6(12): 1916-1924. doi: https://doi.org/10.20546/ijcmas.2017.612.218 